\title{
STRATEGY FORMULATION OF AN AGRICULTURAL MACHINERY DISTRIBUTOR: A CASE STUDY OF PT XYZ
}

\author{
Gunawan Asep Iwan*, Baga Lukman Mohammad, Maulana Agus \\ School of Business, IPB University, Indonesia \\ *E-mail: asepiwan@gmail.com
}

\begin{abstract}
This research aims to formulate strategy of PT $X Y Z$ as an agricultural machinery distributor in Indonesia. The research was carried out by descriptive analysis method. The tools used at this study consist of EFE (External Factors Evaluation) analysis, IFE (Internal Factors Evaluation) analysis, IE (Internal External) matrix analysis, SWOT matrix analysis, and strategic architecture. The results of the analysis show PT XYZ's external strategic factors include 6 opportunities and 6 threats. The internal strategic factors include 5 strengths and 4 weaknesses. In this study PT X YZ obtained EFE 2.617 and IFE 3.047. The position of PT $X Y Z$ in the IE matrix is cell IV which means grow \& build with a choice of intensive and integrative strategies. The results of the SWOT analysis provide PT XYZ with several strategies that can be implemented, namely in the form of 7 SO strategies, 3 ST strategies, 4 WO strategies, and $1 \mathrm{WT}$ strategy. The choice of strategy is then compiled in a strategic architecture to become a road map for PT XYZ in the next 4 years towards the goals and objectives set by the company.
\end{abstract}

\section{KEY WORDS}

SWOT, analysis, strategic architecture, machinery.

Indonesia as an agrarian country faces the challenge of how to increase agricultural productivity to meet increasing needs. Specific agricultural productivity and national competitiveness in general can be improved by the application of agricultural machinery and equipment (agricultural mechanization) appropriately (Tambunan and Sembiring 2007). However, the mechanization of agriculture carried out in Indonesia has not run optimally, which shows that the performance of farmers in adopting technology has not been effective enough, although agricultural machinery can provide economic and financial benefits (Aldillah 2016). On the other hand, the number of agricultural machines is not enough to meet the needs, so it is suggested that the type and number of agricultural machines should be increased as needed with financial support and involving the private sector (Paman et al. 2017). While the accuracy of the number and type of medicine, the concentration of the distribution of locations, the availability of agricultural machinery, the timeliness of supply, and the quality of agricultural machinery's workmanship will affect the increase in access by farmers (Purwantini and Susilowati 2017). The government must also play an attractive role in rural entrepreneurs to work in the field of agricultural mechanization and develop agricultural tools and machinery in rural areas that have great potential in agriculture (Djamhari 2009).

PT $X Y Z$ (not real name) is one of Indonesia's private companies whose main business is in the trading of agricultural equipment and machinery. PT $X Y Z$ is currently a distributor of one of the leading agricultural tractor brands. Besides this, PT XYZ also has other business lines by becoming a distributor of forklifts, generator sets, construction machinery, and trading in heavy equipment parts.

But with this diverse business line, the company is inseparable from the challenges of slow business growth as a result of external and internal changes. The shareholders see how the company's management overcomes these changes from the results of the company's performance reported annually. One of their concerns at this time is the value of sales growth and profits that have not been satisfactory in recent years. 
In terms of business growth, based on the data in Table 1, it can be seen that over the past five years the value of PT XYZ's income has been relatively stagnant. Likewise in terms of profits, from 2016 to 2018 the value continues to decline.

Table 1 - PT XYZ business performance (in billion rupiah)

\begin{tabular}{cccccc}
\hline Description & 2014 & 2015 & 2016 & 2017 & 2018 \\
\hline Revenue & 1003621 & 1006767 & 930753 & 1010028 & 1010050 \\
Gross Profit & 166869 & 184491 & 130811 & 139109 & 84633 \\
\hline
\end{tabular}

Source: PT XYZ internal data.

The existence of these conditions is important for the management of $\mathrm{PT} X Y Z$ to evaluate and formulate business strategies in order to improve performance and support the business development of PT $X Y Z$. In relation to strategy formulation, research is needed to identify the strategic factors of the external and internal environment that influence the current business development of PT XYZ.

Based on this background, the objectives of this study are as follows:

1. Analyzing the strategic factors of the external and internal environment that affect the growth of PT XYZ's business;

2. Formulate a strategy that can be applied to increase the business growth of $P T X Y Z$;

3. Compile the strategic architecture of PT XYZ.

This research is limited to the formulation of the right strategy for PT XYZ by identifying external and internal factors of the company, developing a strategy that is in accordance with the main strategic factors that support business growth and develop a strategic architecture to be recommended to the company.

\section{METHODS OF RESEARCH}

This research was conducted at the head office of PT XYZ having its address at Jakarta. The time of the study was carried out from March to April 2019. The design of this study was to use descriptive research techniques in the form of case studies. This study uses primary data obtained through in-depth interviews, focus group discussions, and surveys. In addition to using primary data, this study also uses secondary data in the form of related literature, annual reports and internal data of PT XYZ company.

Survey respondents were determined by purposive sampling, which consisted of internal and external respondents. The internal party who is the respondent is a member of the Board of Directors consisting of the President Director, Sales Director, Marketing \& Product Support Director, and Business Support Director, as well as General Managers from the Sales, Marketing, Product Support, Finance and Human Resources divisions. While the external party consists of shareholder representatives, management representatives of one of the main suppliers, and customer.

To get an initial picture of strategic factors, focus group discussions were conducted with the general managers of PT XYZ. Then determine the strategic factors of the external and internal business environment. Examination of the company's external and internal environment is very important in the strategy planning process (Arslandere and Ocal 2018). The framework for analyzing the external environment is using PESTEL (Political, Economy, Social, Technology, Environment, Legal) and analysis of the industrial environment 5 Porter forces, while the framework for the analysis of the internal environment is using analysis of organizational functions such as marketing, operations, human resources, and finance (Sammut-Bonnici and Galea 2015).

After that the weighting and rating of the strategic factors is done by using a questionnaire. Weighting and rating of strategic factors produces EFE and IFE matrices which are then mapped into the Internal-External (IE) matrix. The External Factors Evaluation (EFE) and Internal Factors Evaluation (IFE) matrices are the initial input matrices that summarize the synopsis of major environmental opportunities and threats and the company's main strengths and weaknesses, and how they affect the company (Capps and 
Glissmayer 2012). The combined values of EFE and IFE are mapped into the InternalExternal matrix which is divided into 9 cells (David and David 2017). The use of this IE matrix is to obtain business strategies at the corporate level (Winardi 2014).

The SWOT matrix is used to develop selected grand strategies from the IE matrix into several business strategies (Budiman et al. 2018). The strategy obtained from the SWOT matrix is then compiled in a strategic architecture in the form of a road map that is recommended to be implemented by the company in the next 4 years.

Alternative strategies obtained from the SWOT matrix were then mapped into a road map using PT XYZ's strategic architecture in a certain period of time in order to improve current performance to achieve the expected goals. As Pujonggo et al. (2016) uses strategic architecture derived from the results of strategy formulation with SWOT analysis for performance improvement.

Strategic architecture is basically a high-level blueprint for the development of new functions, acquisition of new competencies or the transfer of current competencies which are important links to short-term planning and long-term planning (Hamel and Prahalad 1994). Likewise according to Ungerer and Uys (2005) that the strategic architecture of an institution or company is an approach to broad plans for opportunities as a reflection of the potential path for the future.

In strategic architecture, selected strategies that will be implemented can be mapped to make it easier for executors to read, understand, implement, and evaluate them (Yoshida 2006). Palupiningrum et al. (2015) use strategic architecture to map the strategy focus from year to year. Furthermore Rismon (2010) uses strategic architecture with an external environmental analysis approach using PEST, internal environment analysis using value chains, IE matrix, core competencies, foresight industry, and gap analysis.

The thinking framework of this research is to elaborate the strategy for a strategic architecture in the form of a road map that can be suggested to the management of PT XYZ to guide the implementation of the company's strategy in order to achieve business growth targets (Figure 1).

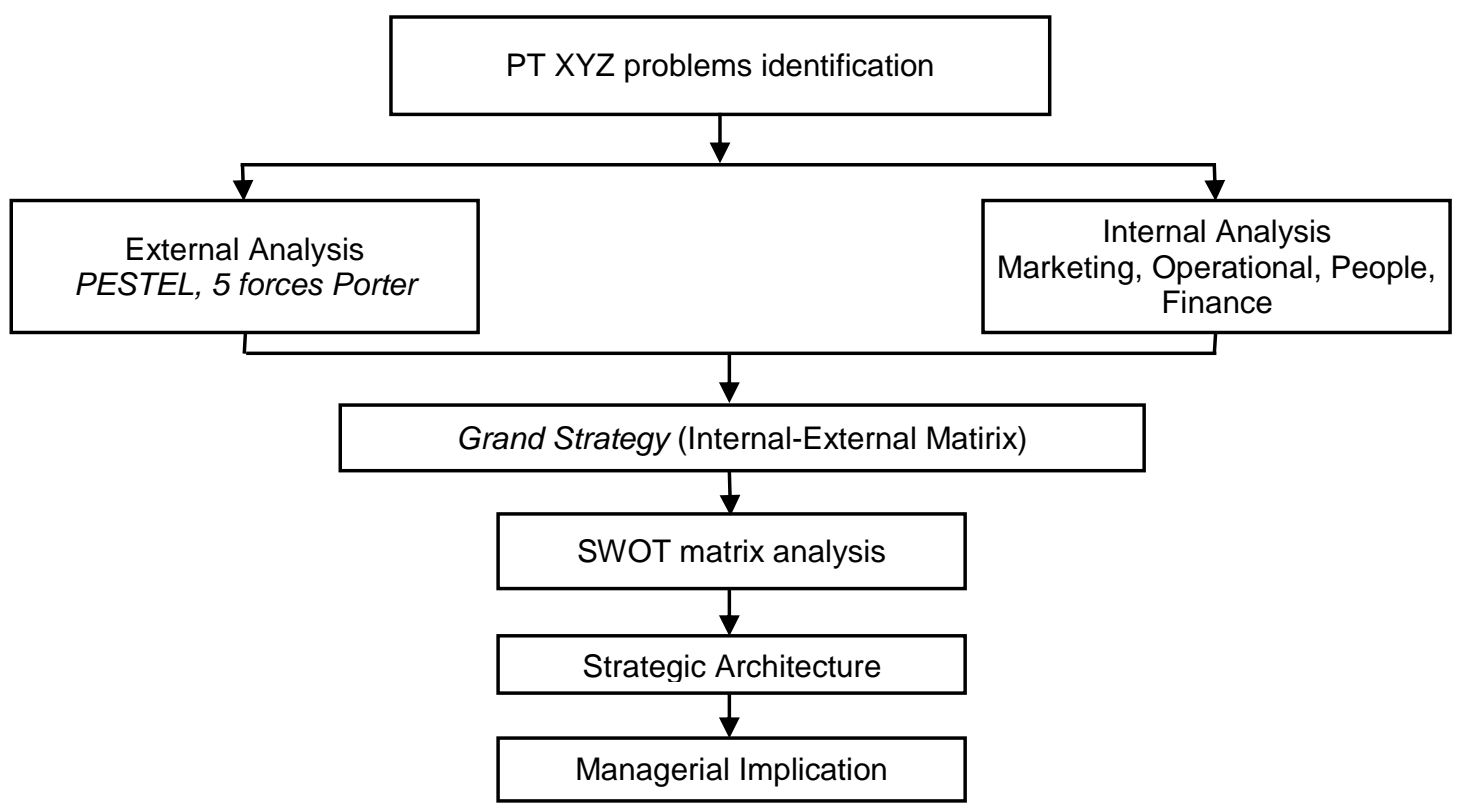

Figure 1 - Research Framework

\section{RESULTS OF STUDY}

PT XYZ's competitive map, especially in the agricultural equipment and machinery business line in Indonesia, is quite tight. The closest competitor in this sector, especially for 4-wheeled tractor farm equipment, is PT Traktor Nusantara (TN) which is the agent of the 
brand farm tractor Masey Fergusson (MF). Besides TN, there is PT Yanmar Diesel Indonesia, which is the direct representative of Yanmar Holdings Co.Ltd. Yanmar brand machinery equipment manufacturer from Japan. In addition there are various companies that sell or produce brands that are circulating in Indonesia such as PT Altrak 1978 (New Holland), PT Probesco Disatama (LS), PT Wahana Inti Selaras (John Deere), PT Corin Mulia Gemilang (Maxxi), PT RUTAN (Iseki), PT Maxi Utama Energy (Deutz-Fahr), PT Satrindo Mitra Utama (Kioti), PT Prima Agra Kencana (Class), PT Garda Nusantara (Dongfeng), PT Belarus Traktor Indonesia (Belarus), CV Karya Hidup Sentosa (Quick ), PT Barata Indonesia (Trabas), and PT Pindad (Pindad).

Foresight industry analysis is used to see a picture of changes in the future of the industry by looking at trends in technological, demographic, regulatory, lifestyle and geopolitical changes (Puryani et al. 2018). An overview of the future of the industry (the foresight industry) of the agricultural machinery and machinery business includes:

1. The machines will be more efficient and save fuel with high productivity. In its development, this machine is also believed to be able to adopt biofuel in the near future. Then there is a trend towards the use of electric powered alsintan. For a description of further developments is the development of autonomous technology.

2. Human resources in the agricultural sector are believed to continue to decline in numbers. Similarly, agricultural land will be increasingly limited. Whereas on the other hand the increasing population requires increasing food production. The combination of these matters will continue to be an impetus for more intensive mechanization of agriculture throughout the agricultural value chain from nursery to post-harvest.

3. Pressure on food needs, especially rice as a staple food also encourages different new ways of managing business in the agricultural sector. The need for efficiency from the process side will greatly increase. Therefore how to manage rice fields traditionally has the opportunity to get alternatives such as by establishing a food estate for rice production from nursery to post-harvest process.

4. In addition to increasing food needs, energy needs will also increase. But the trend is mainly towards renewable energy (renewables energy). For this reason, with the experience of $\mathrm{PT} X Y Z$ as a generator distributor that is a power plant, there is an opportunity for PT $X Y Z$ to enter the electricity business from renewable sources such as using hydropower and biomass. This has already begun by trying to enter the mini hydroelectric power generation business for hydropower and the development of innovative biomass power generators by PT XYZ's engineer team. In relation to the current business of PT XYZ where one of the sub-sectors goes into plantations, especially oil palm, biomass produced from oil palm plantations can be an opportunity to create a biomass power plant business from palm oil waste. In the future it is believed that the electricity industry from renewable energy will grow even more rapidly, and it is expected that PT XYZ is ready to diversify its business to become the leader in the sector.

PT $X Y Z$ is a subsidiary of one of the leading business groups in the field of automotive and heavy equipment in Indonesia. The company's vision is "to be the leading and most trusted company in the industry in providing integrated solutions to customers".

While the company's mission is: 1) Promote superior partnership values with customers and suppliers, both domestically and internationally in the Agriculture, Industrial, Construction, Mining and Energy sectors, 2) Ensure that the products \& services provided are the best for customers and supporting sustainability, 3) Providing the right environment for talents to always improve capability \& productivity. 4) Creating sustainable shareholder value, 4) Becoming the pride of the nation and state.

PT XYZ's business activities were initially trading in agricultural tractors, but in its development $\mathrm{PT} X Y Z$ is currently engaged in trading agricultural equipment and machinery, forklifts, generators and construction machinery. Outside the trading business, PT XYZ has also begun to expand its business into the energy sector by becoming a contractor or EPC (Engineering, Procurement and Construction) contractor for the construction of transmission and power plants. The business is run by PT XYZ through a new subsidiary established in 
2018, namely PT XYZ Energi (PT XYZE). In addition, PT XYZ also entered the Independent Power Provider business of the micro hydro power plant (PLTMH).

Judging from the type of transaction which is also in line with the characteristics of various products and services traded by $\mathrm{PT} X Y Z$ as described previously, $\mathrm{PT} X Y Z$ is a B2B (Business to Business) company because almost all of its customers are companies or individuals who use PT XYZ products and services as goods capital (capital goods) or production equipment for their business. This is in line with B2B understanding as a type of trade transaction based on the exchange of products or services from business to business, and not from business to consumer (Saha et al. 2014).

In order to encourage faster and greater business growth, at the initiative and encouragement of shareholders, PT XYZ carried out the process of adding a business to trade heavy equipment aftermarket parts. In addition, shareholders also revamp their directors through the Extraordinary General Meeting of Shareholders (EGMS) in January 2019.

The organization of PT XYZ consists of a board of directors led by a president director with 3 directors which includes the sales director, marketing director and product support, and the director of business support. Each director oversees one or two division heads (general manager). The divisions in PT XYZ consist of five divisions, namely: sales, marketing, product support, finance, and human resources and infrastructure. In addition to the division, PT XYZ has a functional section, namely the purchasing department under the director of finance, as well as the business development section and corporate planning section under the president director.

The sales department focuses on building strong relationships with customers for each sector so that it can continue to increase sales value. The marketing department focuses on the preparation and implementation of marketing strategies for each product which is its responsibility with the target market share and profitability. In addition to the marketing team, the inventory and logistics analyst team is also under the marketing division. The product support section is responsible for after-sales service, especially in service aspects and management of warranty and claims. The engineer team is also in the product support division. All of these operational divisions are supported by the finance department and their respective human resources and infrastructure.

Table 2 - External Factors Evaluation (EFE) Matrix

\begin{tabular}{|c|c|c|c|c|}
\hline No & Factors & Weight & Rating & $\begin{array}{l}\text { WeightX } \\
\text { rating }\end{array}$ \\
\hline & Opportunities & & & \\
\hline 1 & $\begin{array}{l}\text { The RPJMN (Government National Long Term Plan) establishes superior programs } \\
\text { in the agriculture, industry, infrastructure \& energy sectors. }\end{array}$ & 0,050 & 3 & 0,150 \\
\hline 2 & $\begin{array}{l}\text { Indonesia's economic growth in the agricultural sector, infrastructure, and positive } \\
\text { energy in the last } 5 \text { years. }\end{array}$ & 0,100 & 3 & 0,300 \\
\hline 3 & The market available for the PT XYZ business line is quite large. & 0,117 & 3 & 0,351 \\
\hline 4 & Suppliers of PT XYZ's business lines are available quite a lot globally. & 0,083 & 3 & 0,249 \\
\hline 5 & $\begin{array}{l}\text { The number of agricultural sector workers continues to decline and the conversion } \\
\text { of agricultural land. }\end{array}$ & 0,092 & 3 & 0,276 \\
\hline \multirow[t]{2}{*}{6} & The development of product, information and communication technology. & 0,058 & 2 & 0,116 \\
\hline & Threats & & & \\
\hline 7 & Rupiah fluctuations against US dollar. & 0,050 & 3 & 0,150 \\
\hline 8 & Interest rates are quite high. & 0,100 & 2 & 0,200 \\
\hline 9 & PT XYZ's product switching costs are relatively small. & 0,100 & 2 & 0,200 \\
\hline 10 & There is an import tightening policy on some $\mathrm{PT} X Y Z$ products. & 0,050 & 3 & 0,150 \\
\hline 11 & Customers and suppliers increasingly actively interact directly. & 0,075 & 3 & 0,225 \\
\hline \multirow[t]{2}{*}{12} & Competitors of all PT XYZ business lines are quite numerous and aggressive. & 0,125 & 2 & 0,250 \\
\hline & Total & 1,000 & & 2,617 \\
\hline
\end{tabular}

The current PT XYZ employees are 612 people. Of these, including 113 salespeople, inventory analysts were 16 people, mechanics 136 people, and engineers 5 people. Currently the working period of the majority of PT XYZ's employees is 281 people, less than 5 years, so that their experience and competence must still be optimized. This is important for PT XYZ considering that many of its business fields concern matters of a technical nature and need immediate completion so that customers are satisfied. 
Based on external factors both opportunities and threats that have been determined as important factors and relevant to the business of PT XYZ, then the EFE matrix table is then made by including the weight and rating for each factor obtained from the survey results (Table 2). The EFE calculation of PT XYZ produces a value of 2.617. This figure shows that PT XYZ's external factors have good potential for business.

Based on internal factors both strengths and weaknesses that have been determined as important factors and relevant to the business of PT XYZ, then IFE matrix tables are made by including the weights and ratings for each factor obtained from the survey results (Table 3). The IFE calculation of PT XYZ produces a value of 3.047. This figure shows that PT XYZ's internal factors have enough potential to be optimized to choose a more aggressive business strategy to encourage growth.

Table 3 - Internal Factors Evaluation (IFE) Matrix

\begin{tabular}{|c|c|c|c|c|}
\hline No & Factors & Weight & Rating & WeightX rating \\
\hline & Strengths & & & \\
\hline 1 & PT XYZ has a wide range of Channels \& Networks Distribution. & 0,188 & 4 & 0,750 \\
\hline 2 & PT XYZ has the ability to find \& select suppliers and import processes. & 0,063 & 3 & 0,188 \\
\hline 3 & PT XYZ products have high quality and a good brand image. & 0,141 & 3 & 0,422 \\
\hline 4 & PT XYZ has the ability to provide integrated solutions to customers. & 0,141 & 4 & 0,563 \\
\hline \multirow[t]{2}{*}{5} & PT XYZ has a fairly complete and reliable engineering team. & 0,094 & 4 & 0,375 \\
\hline & Weaknesses & & & \\
\hline 6 & The service to fulfill product support needs is not optimal. & 0,110 & 2 & 0,220 \\
\hline 7 & Handling PT XYZ customer complaints is still not optimal. & 0,050 & 2 & 0,100 \\
\hline 8 & XYZ's corporate brand image is relatively weak. & 0,050 & 2 & 0,100 \\
\hline \multirow[t]{2}{*}{9} & PT XYZ's HR development program is not yet optimal. & 0,100 & 2 & 0,200 \\
\hline & Total & 1,000 & & 3,047 \\
\hline
\end{tabular}

PT XYZ's position in the IE matrix is in cell IV $(3,047 ; 2,617)$ which illustrates that PT $\mathrm{XYZ}$ is fit in the grow \& build with appropriate grand strategy that is intensive (market penetration, market development, product development) or integrative (forward integration, backward integration, horizontal integration).

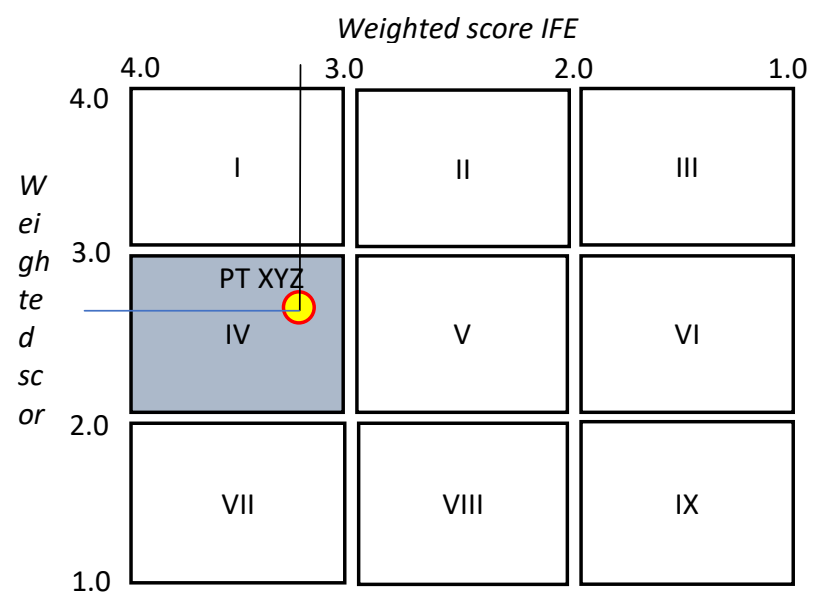

Figure 2 - PT XYZ's position on the Internal-External matrix (IE matrix)

After obtaining the grand strategy from the IE matrix, PT XYZ's strategy formulation analysis was then carried out using the SWOT matrix (Table 4). Strategy selection is mainly focused on SO (Strengths-Opportunities) strategy, which is a strategy that prioritizes the use of power owned by PT XYZ to optimally utilize business opportunities for PT XYZ. Nevertheless, PT XYZ still considers several WO (Weaknesses-Opportunities), ST (= Strengths-Threats), and WT (Weaknesses-Threats) strategies needed to increase business growth. 
Table 4 - SWOT Matrix for PT XYZ business development

\begin{tabular}{|c|c|c|}
\hline External & $\begin{array}{l}\text { Strengths } \\
\text { 1. Distribution Channels \& Networks } \\
\text { 2. Supplier selection and importation } \\
\text { 3. High quality products } \\
\text { 4. Solutions for customers. } \\
\text { 5. Engineering team }\end{array}$ & $\begin{array}{l}\text { Weaknesses } \\
\text { 1. After sales service } \\
\text { 2. Handling complaints } \\
\text { 3. Corporate brand image } \\
\text { 4. HR Development }\end{array}$ \\
\hline $\begin{array}{l}\text { Opportunities } \\
\text { 1. Leading RPJMN in agriculture, } \\
\text { industry, infrastructure \& energy. } \\
\text { 2. Growth in the agricultural, industrial, } \\
\text { infrastructure and positive energy sectors } \\
\text { 3. Big market. } \\
\text { 4. There are many suppliers available } \\
\text { 5. The number of workers in the } \\
\text { agricultural sector has declined } \\
\text { 6. Technological developments }\end{array}$ & $\begin{array}{l}\text { SO strategies } \\
\text { 1. Develop an End to End Agribusiness } \\
\text { business (S1, S4, O2) } \\
\text { 2. College partnerships (S5, O1, O6) } \\
\text { 3. Selection of business portfolios (S2, O3, O4) } \\
\text { 4. Integrated product development and } \\
\text { solutions for customers (S3, S4, S5, O3, O5) } \\
\text { 5. System integration with customer } \\
\text { transactions (S1, O3, O6) } \\
\text { 6. Omnichannel sales channels and global } \\
\text { markets (S1, O5, O6) } \\
\text { 7. Business energy (S5, O1, O2). }\end{array}$ & $\begin{array}{l}\text { WO strategies } \\
\text { 1. Implement a digital sales } \\
\text { planning system (W1, W4, O3) } \\
\text { 2. Implementation of knowledge } \\
\text { management (W2, W4, O3, O6) } \\
\text { 3. Promotion and corporate } \\
\text { branding programs (W3, O3) } \\
\text { 4. Implementation of corporate } \\
\text { academy (W4, O3) }\end{array}$ \\
\hline $\begin{array}{l}\text { Threats } \\
\text { 1. Rupiah fluctuations against the dollar } \\
\text { 2. High interest rates } \\
\text { 3. Small switching costs } \\
\text { 4. Tightening of imports } \\
\text { 5. Customers and suppliers increasingly } \\
\text { actively interact directly. } \\
\text { 6. Number of competitors }\end{array}$ & $\begin{array}{l}\text { ST strategies } \\
\text { 1. Use of non-dollar currencies (S2, S4, T1) } \\
\text { 2. Working with banks, leasing and financial } \\
\text { institutions (S4, T2, T1) } \\
\text { 3. Partnership program with customers (S4, } \\
\text { S5, T3, T5) }\end{array}$ & $\begin{array}{l}\text { WT strategies } \\
\text { 1. Improve after-sales service } \\
(\mathrm{W} 1, \mathrm{~W} 2, \mathrm{~T} 3, \mathrm{~T} 6)\end{array}$ \\
\hline
\end{tabular}

The strategy for the growth of PT XYZ's business that has been selected in the SWOT analysis phase is then mapped into a road map in the strategic architectural design. Strategic architectural design is needed to give priority and stage strategies to achieve the goals and objectives to be achieved by PT XYZ. Strategic architecture also provides an overview of the challenges faced by PT XYZ.

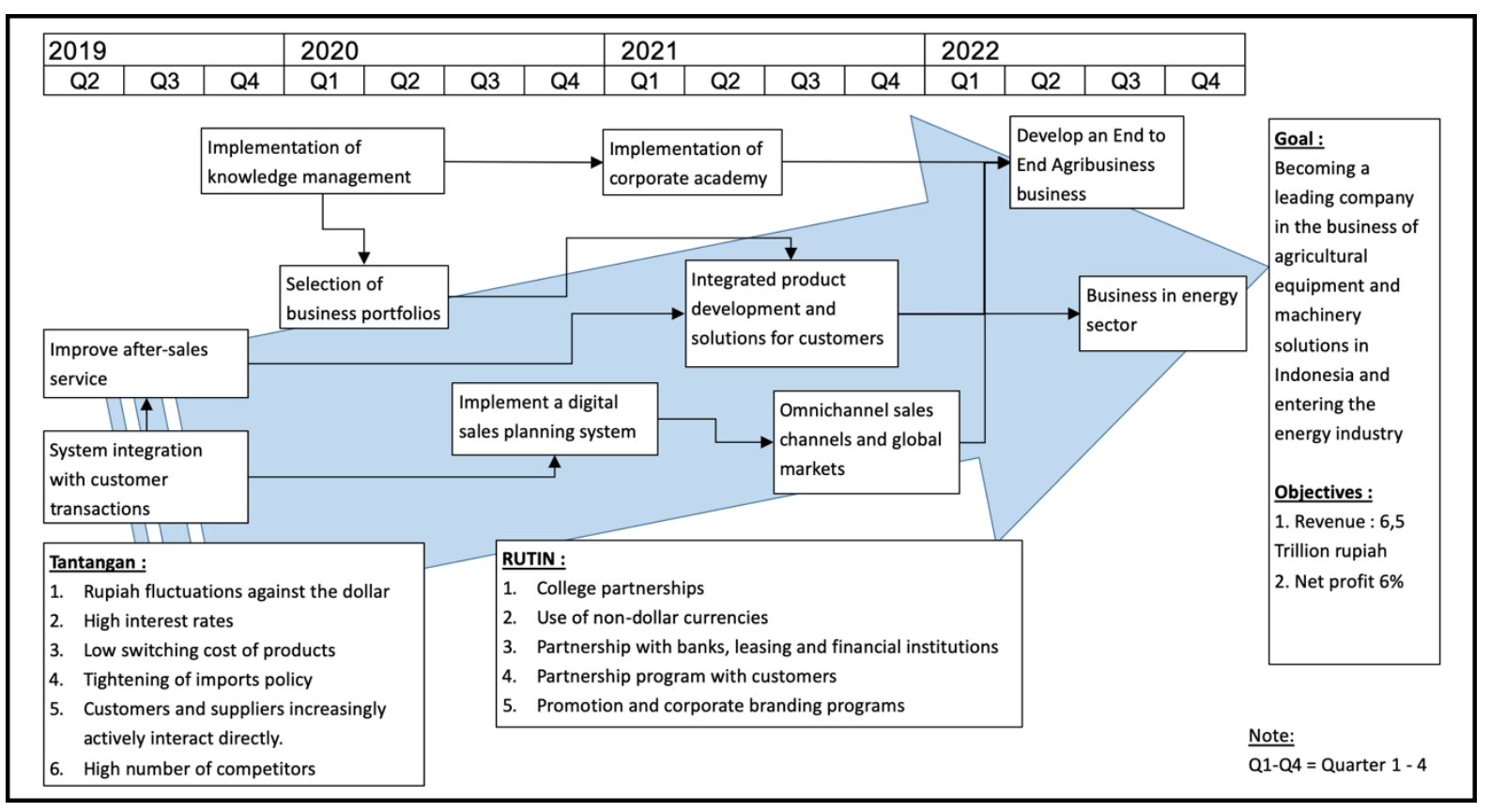

Figure 3 - Strategic Architecture of PT XYZ

The design of the strategic architecture is illustrated by the $X$ axis and $Y$ axis. The $X$ axis shows the time for each stage in the year period and the $Y$ axis describes the program to be implemented.

In PT XYZ's strategic architecture design, the selected strategies are grouped into two categories, namely routine strategies and gradual strategies. Work programs that are 
routinely carried out are chosen taking into account the capabilities and needs of PT XYZ on the output of the program that is needed continuously.

The strategy stages from 2019 to 2022 PT XYZ in the form of a strategy road map can be seen in Figure 3.

\section{MANAGERIAL IMPLICATIONS}

The preparation of strategic architecture for alternative strategies obtained from the SWOT analysis recommends managerial implications for the management of PT XYZ. In the SWOT analysis each selected strategy has been considered to utilize the strengths of weaknesses, overcome weaknesses, gain profit from opportunity factors, and anticipate threat factors. To achieve the objectives announced by the company within the next 4 years all selected strategies must be carried out by every part of the company according to their respective roles and responsibilities. The order of implementation is expected to follow the stages that have been systematically compiled in strategic architecture.

In the first stage, PT XYZ had the opportunity to integrate online transaction systems with key accounts, which in this case could start with the parent company which is the main dealer of PT XYZ. This needs to be done early because the transaction value is very large so this integration will secure the largest portion of revenue while increasing the opportunity for increased sales. Furthermore, this integration process can be offered in stages to other large customers, especially B2B customers.

The next strategy that must also be implemented at the beginning is a very important thing in the business world, namely improving after-sales service to customers. This is consistent with the voice of customers who want PT XYZ to increase the availability and speed of supply of spare parts as well as the adequacy of the number of mechanics. With this increase in services, it is expected that customer trust will increase, resulting in an increase in sales of units sold by PT XYZ. PT XYZ also must begin implementing knowledge management so that all employees, especially sales and operations, always get and master the latest knowledge of the development of PT XYZ products. Good and up to date product knowledge will certainly be a strong capital for PT XYZ in providing integrated solutions to customers.

In the second phase starting in 2020, PT XYZ must begin to create and conduct a business portfolio selection system to ascertain whether the existing portfolio is still the most profitable and encourage growth. In addition, this can be used to complement PT XYZ's lack of product lines. At this stage, PT XYZ must implement a better sales planning system by digitizing sales prospects. This system is expected to increase the accuracy of planning so that it can increase stock readiness, the end of which is that sales increase with the risk of excess inventory being reduced.

In the third stage in 2021, as a continuation of knowledge management, PT XYZ has been able to build a comprehensive corporate academy to improve employee quality, especially in terms of business capabilities. Next to continue portfolio selection, PT XYZ must develop products with integrated solutions to customers so that they not only offer products but can become partners of customers in achieving their business goals. PT XYZ also has to start developing sales channels with omnichannel concepts so that the marketing reach becomes much wider.

In the fourth stage in 2022 after all the previous strategies were implemented, PT XYZ was ready to develop an end to end agribusiness business by looking at market potential both upstream and downstream from the agricultural industry. At the same time, diversification into the energy sector, especially renewable power plants, both hydropower and biomass, is ready. Both of these strategies of course require PT XYZ's competency readiness to be far broader compared to current competencies. The strategy phase in strategic architecture is expected to be able to build the addition and strengthening of the competencies needed to achieve the objectives of PT XYZ as the leading agricultural business and equipment and machinery solutions company and successfully diversify its business into the energy sector. 


\section{CONCLUSION}

In this study the conclusion is the formulation of answers to the objectives of the study. The conclusions of this study are as follows:

1. PT $X Y Z$ has the potential power to be able to take advantage of opportunities in the industry where PT XYZ does business. With PT XYZ's internal strength capital as a Business to Business $\mathrm{B} 2 \mathrm{~B}$ company that is adequate in terms of the strength of the distribution network, the ability to find and select the best suppliers, high quality products with good brand image, the ability to provide integrated solutions to customers and the strength of the engineer team added value for customers, the existence of large business opportunities in the agricultural, infrastructure, energy and mining sectors can be optimized with the right strategies to support the expected business growth.

2. IE analysis positions PT $X Y Z$ in quadrant IV with a grand strategy grow \& build with an intensive and integrative strategy choice. The focus of the strategy in accordance with this position is to focus more on the S-O (aggressive) strategy with 7 strategies than the W-O (conservative) strategy with 4 strategies, the S-T (competitive) strategy with 3 strategies and W-T (defensive) with 1 strategy.

3. With the internal strength and adequacy of PT XYZ's resources, all corporate-level strategies can be implemented by management by taking into account the priority of time and the ability to increase the company's competence over time according to the time period set by management. Strategic architecture in the form of PT XYZ's strategy road map for the period 2019-2022 is arranged as a company reference in implementing all the strategies that have been selected and determined.

\section{RECOMMENDATIONS}

PT XYZ's strategy preparation was made at the corporate level, so to implement it PT $X Y Z$ still had to make a strategy at the functional level as a development of the work program that had been prepared.

PT XYZ's strategic architecture is based on current conditions by considering the foresight industry for the company's business in the future, so it is still advisable for management to periodically evaluate the suitability of the strategy with the external and internal business environment.

To enrich the literatures related to the agricultural machinery and equipment business, further research is recommended from various aspects such as strategy, marketing, operations, supply chains and finance.

\section{REFERENCES}

1. Aldillah R. 2016. Kinerja pemanfaatan mekanisasi pertanian and implikasinya dalam upaya percepatan produksi pangan di Indonesia. Forum Penelitian Agro Ekonomi. 34(2):163-171. Available on: http://ejurnal.litbang.pertanian.go.id/.

2. Arslandere M, Ocal Y. 2018. SWOT analysis as a tool for strategic management and an implementation in a firm in machine industry. Conference paper.

3. Budiman I, Tarigan UPP, Mardhatillah A, Sembiring AC, Teddy W. 2018. Developing business strategies using SWOT analysis in a color crackers industry. J. Phys.: Conf. Ser. 1007 012023.doi:10.1088/1742-6596/1007/1/012023.

4. Capps III CJ, Glissmeyer MD. 2012. Extending the competitive profile matrix using internal factor evaluation and external factor evaluation matrix concepts. Journal of Applied Business Research (JABR). 28(5):1059-1062.doi: 10.19030/jabr.v28i5.7245.

5. David FR, David FR. 2017. Manajemen Strategik: Suatu Pendekatan Keunggulan Bersaing-Konsep. Puspasari N, Puspitasari LN, penerjemah. Jakarta (ID). Penerbit Salemba Empat. Terjemahan dari: Strategic Management: A Competitive Advantage Approach, Concepts and Cases, 15th ed. 
6. Djamhari S. 2009. Kajian penerapan mekanisasi pertanian di lahan rawa lebak Desa Putak - Muara Enim. Jurnal Sains and Teknologi Indonesia. 11(3):157-161. Available on: http://ejurnal.bppt.go.id/index.php/JSTl/article/view/840/673.

7. Hamel G, Prahalad CK. 1994. Competing for the future. Cambridge (US): Harvard Business School Press.

8. Palupiningrum AW, Daryanto A, Fahmi I. 2016. Strategic architecture for School of Business, Bogor Agricultural University. Higher Education Studies. 6(1):40-52.doi: 10.5539/hes.v6n1p40.

9. Paman U, Khairizal, Wahyudy HA. 2017. Kebutuhan mesin pertanian and tenaga untuk mekanisasi padi skala kecil di Kabupaten Kampar, Provinsi Riau. Jurnal Dinamika Pertanian. 12(2):11-18.https://doi.org/10.25299/dp.2017.vol33(2).813.

10. Pujonggo RY, Syarief R, Rifin A. 2016. Strategic Architecture of Inspectorate General Ministry of Trade Republic of Indonesia. International Journal of Scientific and Research Publication [internet]. [diunduh pada 2019 Februari 22]; 6(10):197-207. Tersedia pada: http://www.ijsrp.org/research-paper-1016/ijsrp-p5833.pdf.

11. Purwantini TB, Susilowati SH. 2017. Dampak penggunaan alat mesin panen terhadap kelembagaan usaha tani padi. Analisis Kebijakan Pertanian. 16(1):73-88. DOI: 10.21082/akp.v16n1.2018.73-88.

12. Puryani, Baga LM, Saptono IT. 2019. Formulasi strategi bisnis perusahaan original equipment manufacturer (OEM) studi kasus di PT XYZ. Jurnal Aplikasi Bisnis and Manajemen. 5(1):13-23.http://dx.doi.org/10.17358/jabm.5.1.13.

13. Rismon B. 2010. Arsitektur strategik Perum Pegadaian [tesis]. Bogor (ID): Institut Pertanian Bogor.

14. Saha SK, Aman A, Hossain MS, Islam A, Rodela RS. 2014. A comparative study on B2B Vs. B2C based on Asia Pacific region. International Journal of Scientific \& Technology Research. 3(9):294-298. Available on: www.ijstr.org.

15. Sammut-Bonnici T, Galea D. 2015. SWOT analysis. Wiley Encyclopedia of Management. Edited by Professor Sir Cary L Cooper. John Wiley \& Sons.

16. Tambunan $\mathrm{AH}$, Sembiring EN. 2007. Kajian kebijakan alat and mesin pertanian. Jurnal Keteknikan Pertanian. 21(4):1-16. Available on: http://journal.ipb.ac.id/.

17. Ungerer M, Uys K. 2005. A theoretical model for developing core capabilities from an intellectual capital perspective (part 2). Journal of Industrial Psychology. 31(2):7-13. Available on https://core.ac.uk/download/pdf/54185350.pdf.

18. Winardi. 2014. Strategi operasional bisnis konsultan di Jakarta untuk meraih peluang yang lebih baik. Jurnal MIX. 4(2):135-150. Availbale on: http://digilib.mercubuana.ac.id/.

19. Yoshida DT. 2006. Arsitektur Strategik: Sebuah Solusi Meraih Kemenangan dalam Dunia yang Senantiasa Berubah. Jakarta(ID): Elex Media Kompetindo. 